\title{
ПРОБЛЕМА СПОЛУЧЕННЯ ЗНАННЯ І ВІРИ В ФІЛОСОФІї ОСВІТИ КИЇВСЬКИХ АКАДЕМІЧНИХ МИСЛИТЕЛІВ ХІХ-ПОЧАТКУ ХХ СТОЛІть
}

\begin{abstract}
С.Л. Кузьміна
У наш час в українському суспільстві, що $є$ полікультурним, актуальне питання присутності віри в освіті поки не підіймається. Законодавство України інерційно закріпило старий радянський принцип «світської школи», яким проблема зв'язку релігії з освітою взагалі ігнорується. Тим часом, сьогодні переважна більшість українських громадян, хоч і різною мірою активно, але сповідують якусь релігію, а представники релігійних організацій так чи інакше проникають у школи. Рано чи пізно буде усвідомлена необхідність легітимізації таких «проникнень» і для цього може знадобитися теорія, що пояснювала би роль і значення віри в освіті. Зрозуміло, що розробка цієї теорії $\epsilon$ компетенцією філософії освіти. Проте в пострадянському інтелектуальному просторі згадана філософська дисципліна тільки оформлюється, а ті вектори розвитку, які в ній накреслилися, спрямовані радше технократично, ніж гуманітарно. А отже, проблема віри в освіті ще надовго залишиться поза полем досліджень або будуть запропоновані неадекватні засоби її розв'язання. Як і в багатьох інших, у даному випадку вітчизняній гуманітаристиці, щоб налаштуватися на потрібну хвилю і усвідомити власну самобутність, варто звернутися до минулого і спробувати осмислити досвід традиції, перерваної великою соціальною катастрофою початку ХХ ст.

У Poсії XIX - початку XX ст. питання про зв'язок віри і знання, віри і освіти особливо активно досліджувався філософами духовних
\end{abstract}

Актуальні проблеми духовності

(Відп. ред.: Я.В. Шрамко)

Кривий Ріг (2007), 125-134 
академій i, почасти, університетів. До цього їх спонукали як палкі суспільні дебати з приводу освітніх реформ, під час яких все голосніше лунали гасла емансипації школи від Церкви, так і певні особливості російської концепції духовної освіти, що, згідно вимогам Статутів, повинна була орієнтувати учнів на створення «цілісного християнського світогляду» в плідному синтезі віри і розуму. Помітний внесок в осмислення філософсько-педагогічних аспектів цієї проблеми зробили професори Київської духовної академії та Університету Св. Володимира Сильвестр Гогоцький, Памфіл Юркевич, Маркелін Олесницький, Петро Ліницький, Микола Маккавейський, Василь Зеньковський. Всі вони, поряд з філософськими і богословськими дисциплінами, викладали педагогіку. I не лише в академії та університеті, а й на Вищих жіночих курсах, в гімназіях, інститутах, духовних і учительських семінаріях. Як же в системі поглядів цих мислителів визначалася роль віри в освіті? Це можна зрозуміти, якщо позначити основні вузли їхнього антропологічного дискурсу.

Одним із найстарших у когорті київських академістів XIX ст. був Сильвестр Гогоцький (1813-1889), який почав свою п'ятдесятирічну наукову кар'єру в Київський духовній академії, а згодом перейшов до Університету Св. Володимира. Людина, на думку цього мислителя, відрізняється від усіх істот тварного світу своєю універсальною природою «мікрокосму». Але як «моральнісна особистість», що наділена здатністю до свідомої діяльності, вона повинна не просто пасивно відобразити, а творчо, вільно поєднати два виміри буття - фізичне i моральнісне. В який спосіб? Через саморозвиток, вважає С. Гогоцький. Саме категорія саморозвитку, що розуміється в гегелівському дусі, на його погляд, дозволяє осягнути істинний сенс людської свободи. Остання, обмежена фізичними законами «сліпої необхідності», здійснюється в моральнісний діяльності «свідомого самовдосконалення», в узгодженому саморусі рослинно-тваринного і свідомо-діяльнісного начал. Виходячи з цього, сутність освіти С. Гогоцький бачить у гармонії постійного руху сил людини, самовдосконаленні в напрямку «щонайкращого стану», коли внутрішні іфічні потяги домінують, підкорюючи собі тілесне як інструмент символічного самовиразу [3, с. 2, 19, 109]. Що ж живить енергію моральнісних потягів особистості? В «науці виховної освіти» мислитель, маючи на увазі педагогічні тези Іммануїла Канта, надає великого значення в цьому процесі звичкам, які культивуються під впливом догляду, дисципліни, навчання, взагалі «виховного середовища». Втім навряд чи він вважав їх достатніми для досягнення людиною вищого щаблю «самоосвіти» - щаблю свідомого самовдоско- 
налення. Адже, сходячи до нього, людина задається смисложиттєвими питаннями про «значення самого світу явищ», «про відношення між світом моральнісний і фізичним». А щоб відповісти на них, вважає С. Гогоцький, потрібна інша, ніж звична довіра до авторитету, віра, що коріниться «всередині нас, у дусі, в моральнісний природі». Мислитель асоціює її з кантіанськими «ідеями розуму» і водночас надає їй значення «живильної сили», яка мотивує моральнісну діяльність, а отже і освіту як її втілення [2, с.740-741].

Яким же чином освіта має підкріплювати тенденцію розуму поєднувати знання з вірою в цілісному світоспогляданні? На думку С. Гогоцького, цьому має сприяти «дух навчання» як певне ставлення, а говорячи сучасною мовою, психологічна установка, через призму якої предмет навчання розглядається відносно «ідеї життя взагалі, згідно 3 прийнятою системою світогляду, хоча би ми і не викладали самої системи» [1, с.632]. Дух навчання професор характеризує як у предметному, так і в суб'єктивному або чисто педагогічному сенсах. Позаяк освіта призначена пробуджувати вищі моральнісні потяги людської природи, то, вважає він, предметний дух навчання не буде істинним i сам собі зрадить, якщо в предметах навчання не проводитиме відповідний принцип. А саме, у викладанні всіх наук має просвічувати «визнання вищого, божественного начала, так само, як одне життя просякає і найближчі до серця, і найвіддаленіші від нього органи тіла» $[1$, c.633]. А в науках, що вивчають виключно фізичний світ, навчанням нехай принаймні не заперечуються «переконання щодо буття верховного творчого розуму і вищого покликання людини» $[1$, с. 634$]$. В суб'єктивному вимірі дух навчання, за С. Гогоцьким, має увиразнюватися в особистості педагога, який повинен бачити у вихованці «майбутнього члена царства розуму, царства духу», допомагаючи йому духовно зростати [1, с.634].

Антропологічні погляди Памфіла Юркевича (1826-1874), професора Київської духовної академії, а з 1861 р. - професора філософії Московського університету, співзвучні поглядам С.Гогоцького. Він так само переконаний, що людській природі, яка поєднує духовне і матеріальне начала, притаманні духовно-моральнісні потяги і здатність до свободи. Проте в філософсько-педагогічній концепції цього мислителя помітні не лише рецепції німецької класичної філософії, а й потужний вплив платонізму і патристики. Осмислюючи сутність освіти, П. Юркевич знаходить, що в ній як правило превалює певний філософський принцип, якого дотримується певна культура. В християнській цивілізації він знаходить два таких принципи. Це Платонівська 
ідея як віра в «об'єктивне благо» і Фіхтеанське Я як «особистий рефлекс і культура особистих сил» [13, с. 108]. Передумовою обох слугує переконання в необхідності звільнити людину через освіту від «внутрішньої суб'єктивності» хаосу пристрастей і бажань, від «сліпого впливу речей на свідомість» для поєднання трьох ㄲï темпераментів - природного, історичного і вічного і виконання людського призначення до Спасіння. Але якщо «принцип культури особистих сил», передбачаючи розвиток «сталих форм душевного життя» або звичок, виграє в освіті більше технічну роль, то «принцип віри», через засвоєння зразків та ідеалів або «очевидностей естетичної, моральнісної, логічної», просвітлює і надихає людину на розкриття в творчій самодіяльності горизонтів свободи спрямування сил і любові до Бога і людства.

Вітчизняну школу XIX ст. П. Юркевич критикував за механічне поєднання, а фактичне роз'єднання в двох «мікроскопічних факультетах» - богословському і філологічному - цих важливих принципів освіти. Для нього є очевидною та небезпека, на яку наражаються внаслідок цього суспільство і культура в цілому. «Я уявляю собі живо, пише П. Юркевич, - цей порядок, який немовби навмисно розрахований на те, щоб утворити у нас поки не існуючі партії клерикалів, що відвертаються від цивілізації, і партії гуманістів, що відвертаються від життя» [13, с.9]. Натомість П. Юркевич надає перевагу гербартіанській концепції «виховного навчання», яке, вважає він, має передусім накарбувати в свідомості та серці вихованця правильні моральніснорелігійні переконання. Кожна наука, на думку мислителя, володіє в цьому сенсі великим виховним потенціалом, позаяк дає помітити уважному і зацікавленому погляду за зовнішнім світом явищ світло істини від світу вищого, духовного [12, с. 236]. А тому кожна наука може сприяти розвиткові у вихованці здатності до засвоєння ідеального боку життя, вигострити його чутливість до краси і гармонії, збудити в ньому безкорисливу любов до істини. Відбувається це, вважає П. Юркевич, за умови не стільки навчання релігії, релігійності, скільки внесення в кожний навчальний предмет духу релігійності, який увиразнюється в ставлення до всього зразкового, істинного, прекрасного як до священного [12, с. 236]. Цю ідею, зауважує він, вперше вніс у педагогіку Сократ, у діяльності якого пізнання істини, добра і досконалості було за своїм справжнім духом Богопізнанням і служінням Богу [12, с. 237]. Проте мислитель застережує від спроб перетворити «вказівки на присутність вищих начал у звичайних явищах» на тези для заучування, ба й навіть товчіння, адже «моральнісно-релігійні переконання вкорінюються в душу тим сильніше і глибше, чим менше їхній предмет 
робиться звичайним і щоденним ... знайомим нам до банальності» $[12$, c. 238].

Петро Ліницький (1839-1906), мислитель, чия 40-річна творча діяльність пройшла в стінах Київської духовної академії, так само, як його попередники будував свою філософсько-педагогічну теорію на постулаті дуалізму людської природи, вважаючи, що їй притаманний потяг до досконалості, потреба здійснення істинної свободи духу [5, с. 98]. Особливу зацікавленість П. Ліницького викликала проблема співвідношення віри і знання, які він розглядав як принципово відмінні й водночас взаємопов'язані здібності душі. Простежуючи згубні наслідки несвідомого змішування віри і знання в філософії, науці й освіті, мислитель намагався окреслити формат їхньої плодотворної взаємодії. Якщо порівнювати структурно-психологічно, розмірковує він, то знання, що складається з емпіричного і умоглядного компонентів, цілком сумісне з релігійними ідеями як чистим умоглядом (на що звернув увагу ще Кант). Тоді, щоб дізнатись, яка роль належить вірі в процесі пізнання, необхідно визначити модальність релігійних ідей. На думку мислителя, як гранично ідеальні, вони аналогічні естетичним i, отже, так само виховально впливають на дух людини. Але якщо мета естетичних ідей - духовна насолода почуттів і фантазії, то релігійних - духовне очищення, що вимагає не спокійного споглядання, а зусиль, боротьби, жертви. В такому випадку безпосередня мета віри полягає в управлінні життям і діяльністю людини. Це підтверджується відношенням розуму до визначень віри, які засвоюються не як логічна, а як моральнісна необхідність i, переплавляючись у переконання, стають мотивами, тобто «рушійними причинами дій» свободної волі. Маючи це на увазі, П. Ліницький заключає: віра є принцип єдності знання і діла, науки і життя [5, с. 31-43]. Він вважає, що завдяки цьому принципу різні типи релігійного життя породжують і різні типи освіти. Втім, в Росії актуальніше те, що і освіта здійснює зворотній вплив на релігійне життя. Для П. Ліницького яскравою ілюстрацією цього слугує літературно-художній ухил післяпетровського просвітництва, який хоч і сприяв розвитку проповідницького мистецтва, все ж таки згубно позначився на релігійності, що стала пішла шляхами пошуків у християнстві особливих почуттів і настроїв, а не божественної благодаті. А з поворотом суспільної свідомості в бік «науковості», хибно витлумаченої в позитивістському дусі, в освіті права віри почали взагалі заперечуватись. Як же так побудувати освіту, замислюється П. Ліницький, щоб віра набула значення її органічної, моральнісноспрямовуючої частини? Він вважає, що єдність християнської віри i 
пізнання можна встановити, якщо поставити освіту на умоглядно-філософський фундамент, складений з математики як «знаряддя природознавства» і філософії як «математики» гуманітарних наук [5, с. 397404].

Аналогічних висновків доходить ще один професор, що більше тридџяти років прослужив у Київський духовній академії,-Маркелін Олесницький (1848-1905). Його уявлення про роль віри в галузі освіти визначалися переконанням, що «релігія поєднує і поповнює всі найвищі інтереси людини і надає духу його повне задоволення і спокій, яких він не може знайти в науці, мистецтві і житті ... концентрує всі сили людської душі й надає людині можливість скласти собі закінчений світогляд» [10, с.271]. Але не лише як миротворна сила i гносеологічний концентр виступає релігія в філософсько-педагогічній концепції М. Олесницького. Віра тут є бодай не головним чинником моральнісного становлення особистості, яке відбувається за «творчим принципом» самовдосконалення. А сенс його полягає в тому, що, здійснюючи цілеспрямовану діяльність, людина опиняється в полі напруги між полюсами ідеальних вимог і реальних можливостей. Моральнісну цінність вчинку, що знімає цю напругу, визначають, згідно Кантовим критеріям, за змістом мотивів. Але, звертає увагу М. Олесницький, мотиваційна сфера особистості формується не лише в результаті дії природних законів. Вона такою ж самою мірою $є$ і плодом зусиль людини, позаяк певне уявлення-потреба набуває сили лише тоді, коли «воля енергійно іде йому назустріч», «притягує його до себе», «перетворює на частину самої себе» [9, с. 52-53]. Саме в цьому воля керується вимогою моральнісного закону, а точніше вірою, і здійснює свою свободу, спрямовуючи розвиток особистості або за законом добра, здобуття божественної благодаті (нормальний шлях розвитку духовного єства людини), або за законом зла (аномальний рух волі з патологічними наслідками для особистості) [9, с.42]. Якщо вважати сутністю освіти утворення моральнісного характеру, то, на думку М. Олесницького, істинним центром, що поєднує весь навчальний матеріал, має бути не будь-який предмет, а сам вихованець [11, с. 30]. 3 цієї точки зору, розмірковує мислитель, цілком логічним буде, не витискаючи природничу складову змісту освіти, збільшувати вагу історичної, позаяк історія і людське життя є предметом участі й співчуття, з яких виникає душевний настрій і складається моральнісна гідність людини. Найприроднішими для цього в початковій школі є християнське вчення і рідна мова. Втім така вимога викликає питання, коли йдеться про профільні навчальні заклади - класичні гімназії та реальні училища, освіта в 
яких заглиблює в давньокласичну літературу або природничі науки. Проте і тут головним, на переконання М. Олесницького, повинен стати християнський принцип, як такий, що фокусує навчання, незалежно від профілю, навколо душі вихованця з $\dddot{1}$ глибинними духовними потягами до моральнісної досконалості [11, с. 31-37].

Останній професор педагогіки Київської духовної академії-Микола Маккавейський (1864-1919) уже не стільки теоретично доводив необхідність віри в освіті, скільки зосереджувався на проблемі християнізації російської школи. I в цьому головним вважав принцип, на який варто би звернути увагу теперішнім реформаторам від освіти. Сутність його полягає в тому, що школу слід не ламати й будувати заново, а якомога обережніше модифікувати, замінюючи в ній нові елементи і створюючи простір свободи для творчості. Так, найбільш натуральним засобом християнізації навчальних планів і програм утилітарно спрямованої реальної школи М. Маккавейський бачив у тому, щоб поряд з Законом Божим поставити естетичні предмети, які допоможуть створити настрій, коли людина «з особливою легкістю приникає до світу безкінечного, божественного, переживає стан релігійного натхнення» $[8$, с. 309-310]. А в класичній школі мислитель пропонує пов'язувати викладання релігійних дисциплін з всім змістом класичних наук, доповнюючи його «батьківщинознавчими» предметами, що найяскравіше відображають особливості російського національного світогляду і самосвідомості [6, с. 606]. Але християнізація школи так і залишиться мрією, вважає М. Маккавейський, без справжнього приєднання до Церкви через введення інституту пастирства в особі священика з повним обсягом обов'язків служіння (учительного, священицького, пастирсько-педагогічного) саме в її стінах [8, с.411-415].

Своєрідним підсумком розвитку київської філософсько-педагогічної думки XIX - початку XX ст. стала творчість професора Університету Св. Володимира, пізніше - відомого філософа російського зарубіжжя Василя Зеньковського (1881-1962). Але якщо дискурсивні практики П. Юркевича, С. Гогоцького, М. Олесницького в полі освіти хоч і стояли на фундаменті православної догматики і патристики, значною мірою залежали від німецької педагогіки, то В. Зеньковський тему дитини і дитинства розглядає безпосередньо в світлі християнської антропології, включаючи до неї софіологічне вчення. За його концепцією, духовне начало і початок особистості в дитині складає образ Божий, укорінений у Бозі-Творці й пов'язаний з всією Софією як ідеальною основою тварного світу. Водночас, єдиносущна всьому людству, дитина починає своє існування з тим роздвоєнням духовного 
життя, яке утворює підгрунтя гріховності. Відповідно цій «триєдності» центру особистості, її розвиток іде у трьох напрямах, виявляючи творче начало своєрідності в діяльності основних сил, начало свободи через одвічну суперечність добра і зла, начало соціальності через засвоєння мови [4, с. 104-105]. Проте, наголошує В. Зеньковський, посилаючись на результати досліджень психології мислення у Вюрцбурзькій школі, феноменології, інтуїтивізмі, духовне життя не є похідною емпіричних процесів у душі або тілі й рівночасно воно потребує емпіричного матеріалу, в якому опосередковується його розвиток. Тим самим, вважає він, педагогіка отримує можливість поточнити функції емпірії в духовному становленні, усвідомити різнорідність і взаємозалежність двох сфер людського буття. Яким же чином створити в школі сприятливу атмосферу для «тендітної квітки релігійності»? 3 одного боку, зауважує В.Зеньковський, штучно виокремити з цілісного душевного життя релігійну сферу абсолютно неможливо і згубно, адже це загрожує розладом психічної рівноваги, ієрархї сил. 3 іншого, нормальний розвиток релігійної сфери виявляється дуже важливим для духовного здоров'я. «Дитина потребує, - підкреслює мислитель, - того світорозуміння, за якого для неї все в світі має сенс, все сходить до Творця і Отця Небесного... Якщо ми, - продовжує він, - висуваємо ідеал всебічного розвитку особистості, вільного розкриття їі, чому ж ми бажаємо пригнітити цей бік душі?» [4, с.66].

На думку В.Зеньковського, зазначена суперечність знімається в ідеї церковної школи. Позаяк релігійна сфера особистості посідає центральне місце в ієрархії душевних сил, то і немає жодної психологічної необхідності для її живлення давати багато релігійного матеріалу. Все залежить від того, яку духовну установку дає школа, який дух панує в ній. Мислитель переконаний, що завданням церковної школи є створення атмосфери вільної, безмежної любові до Церкви, справжньої, вільної і творчої спрямованості до Бога. Щоправда, головною умовою появи такої школи він вважає подолання «наївної» різновекторності сучасної культури, що зосереджується на полюсах церковності й антихристиянства. «Ми повинні, - закликає В. Зеньковський, - створювати оази релігійної культури... ми повинні для себе, нікому не нав'язуючи, шукати справжньої, а не зовнішньої сполученості Церкви і світу, Церкви і культури» [4, с. 161-162].

Отже, як бачимо, в інтелектуальному середовищі київських мислителів-академістів протягом півстоліття проблема віри в освіті залишалась актуальною. Вони були одностайні в тому, що віра і релігія, беручи безпосередню участь у самодіяльному формуванні мотиваційної 
сфери особистості, складають смислове ядро освіти, за генетичними кодами якого відбувається розвиток «периферійних» сил особистості. Їхні міркування, попри всі історичні зміни, що відбулися в ХХ ст., змушують, на наш погляд, серйозно замислитися щодо правомірності «атеїстичного диктату»в школі.

\section{1 Бібліографія}

[1] Гогоцкий C.C. Дух обучения // Философский лексикон. - К., 1862. - T. II. - C. 630-634.

[2] Гогоцкий C.C. Знание // Философский лексикон. - К., 1862.T. II. - C. $738-744$.

[3] Гогоцкий C.C. Краткое обозрение педагогики или науки воспитательного образования. Вып. 1. - К., 1879.

[4] Зенъковский В.В. Проблемы воспитания в свете христианской антропологии. - М.: Изд-во Свято-Владимирского Братства, 1993.

[5] Линицкий П.И. Пособие к изучению вопросов философии (элементы философского миросозерцания). - Х., 1892.

[6] Маккавейский H.K. Современные педагогические блуждания (по поводу издания С.А. Рачинского “Absit Omen", СПб., 1901) // Труды Киевской духовной академии. - 1901. - № 12. - С. 580-609.

[7] Маккавейский H.K. K вопросу о религиозном воспитании в нашей средней школе // Труды Киевской духовной академии. - 1903. № 3. - C. 395-432.

[8] Маккавейский H.K. Проблема воспитания по Спенсеру // Труды Киевской духовной академии. - 1906. - № 7-8. - С.610-640. № 12. - С. 461-494. - 1908. - №6. - С. 256-280. - 1909. - № 10. C. 270-311. - № $12 .-$ C. 593-635.

[9] Олесницкий М.A. История нравственности и нравственных учений. Вып. 1. - К., 1882.

[10] Олесницкий M.А. Курс педагогики: Руководство для женских институтов и гимназий, для высших курсов и для всех занимающихся воспитанием детей. Вып. 1. Теория воспитания. - K., 1885. 
[11] Олесницкий M.A. Курс педагогики: Руководство для женских институтов и гимназий, для высших курсов и для всех занимающихся воспитанием детей. Вып. 2. Теория обучения. - K., 1887.

[12] Юркевич П.Д. Курс общей педагогики с приложениями.-М., 1869.

[13] Юркевич П.Д. План и силы для первоначальной школы // ЖМНП. - 1870. - № 3. - С. 1-29. - № 4. - С. 95-123. 